\title{
Narrow Substrate Requirements Alongside Rapid Substrate Turnover for Wood-Inhabiting Fungi: A Case Study of Pleurotus Calyptratus (Agaricales, Basidiomycota) in Ukraine
}

\section{Oleh Prylutskyi ( $\sim$ prylutskyi@karazin.ua )}

V. N. Karazin Kharkiv National University https://orcid.org/0000-0001-5730-517X

Iryna Yatsiuk

University of Tartu: Tartu Ulikool

Anton Savchenko

University of Tartu: Tartu Ulikool

Maryna Kit

National Scientific Center "Institute of Experimental and Clinical Veterinary Medicine"

Oleksii Solodiankin

National Scientific Center "Institute of Experimental and Clinical Veterinary Medicine"

Dmitry Schigel

University of Helsinki Department of Biosciences: Helsingin yliopisto Bio- ja ymparistotieteellinen tiedekunta

\section{Research}

Keywords: Wood-inhabiting fungi, Deadwood, Aspen, Occupancy, Oyster mushrooms, Conservation, Monitoring

Posted Date: December 9th, 2020

DOl: https://doi.org/10.21203/rs.3.rs-122044/v1

License: (c) (i) This work is licensed under a Creative Commons Attribution 4.0 International License. Read Full License 


\section{Abstract}

\section{Background}

Pleurotus calyptratus is a wood-inhabiting oyster mushroom which produces fruiting bodies on logs, stumps and branches of both dead and living Populus tremula and $P$. alba. Easily recognisable in the field fruit bodies and strict and steady fruiting period make this species an attractive model object for investigations of ecology of wood-inhabiting fungi. This fungus is rather common in Ukraine, but considered rare in many other European countries.

To explore species biology in relation to its rarity issues, we analyzed substrate requirements and habitat supply for $P$. calyptratus in two sites in Eastern Ukraine, as well as monitored patterns of fruit body production in three large aspen stands over 6 years. In addition, patterns of mycelial presence of $P$. calyptratus mycelia were studied in living aspen trees using custom species-specific primers.

Results

Study demonstrates potential suitability of a wide range of life / decomposition stages of aspen or white poplar tree trunks for $P$. calyptratus. This window of suitability, however, is rather short: dying of freshly dead trees, rarely exceeding two years) regardless of tree age, volume, position or other parameters. Moreover, mycelium presence of $P$. calyptratus was detected in the living tissues of host trees. These findings supported hypotheses of early substrate colonization and latent mycelial development of $P$. calyptratus before the substrate reached a stage suitable for fructification.

\section{Conclusions}

Confirmed by a combination of fruit body survey and detection of mycelial DNA, P. calyptratus demonstrates an ecological strategy which combines both strict substrate requirements and rapid substrate turnover. We suppose that such a strategy may be widely distributed among wood-inhabiting agarics.

\section{Background}

Pleurotus calyptratus (Lindblad ex Fr.) Sacc. is a wood-inhabiting oyster mushroom which develops fruiting bodies on logs, stumps and branches of both dead and living Populus tremula L. and P. alba L. The fungus is characterized by a prominent partial veil, which makes it easy to identify in the field (Knudsen \& Vesterholt 2012).

$P$. calyptratus was first described by Mats Adolf Lindblad in 1845 from Högholmsskär in Lake Mälaren, Sweden. Next time Pleurotus calyptratus was found almost 90 years later, in 1931 in Austria. Since then, the species has been reported from a few countries in Europe, including Austria, Czech Republic, Estonia, Finland, Germany, Hungary, Latvia, Lithuania, Russia Slovakia, Ukraine and former Yugoslavia (Soop et al. 1995). 
This species is included in the Red Lists of Norway (Vulnerable: The Norwegian Biodiversity Information Centre (NBIC) 2019), Sweden (Endangered: SLU Artdatabanken 2020), Finland (Endangered: Hyvärinen et al. 2019), Estonia (Near Threatened: Saar et al. 2019), Germany (G category: Bundesamt für Naturschutz 2009), Czech Republic (Endangered: Holec \& Beran 2006), and Poland (“E - wymierające” category: Mirek et al. 2006). According to the Red List of Norway, P. calyptratus meets the IUCN criterion D1 - very small or geographically very restricted population (Kålås et al. 2010). In the Red List of Finland, the species is reported as EN based on the criteria B2ab(iii) - small distribution area and decline, or strong fragmentation of occurrence, or extreme fluctuations in population size. Forest management activities and following decreasing amounts of decaying wood are mentioned as the main threatening factors (Finnish Environment Institute et al. 2019).

The known occurrences of $P$. calyptratus suggest that the fungus' range almost entirely follows the one of Populus tremula, covering the territory of Europe (except the Mediterranean zone) and Northern Asia (Rogers et al. 2020). However, according to the GBIF-mediated data (GBIF.org, 2020a), the species occurrence rate increases towards the east. In Ukraine $P$. calyptratus may be considered as an occasional species (Prylutskyi 2011).

Considering the fact that Northern and Western Europe is generally better mycologically investigated (Andrew et al. 2017; Větrovský et al. 2020), and that the aspen and poplars there are not less common (Brus et al. 2012; Caudullo \& de Rigo 2016; GBIF.org 2020b) than in the Eastern Europe or Asia, the reasons for such rarity gradient of $P$. calyptratus remain unclear. Therefore, there is a need to study ecological traits, substrate and habitat preferences, and population dynamics of $P$. calyptratus more targetedly.

We hypothesized that the local rarity of $P$. calyptratus can be explained by $(\mathrm{H} 1)$ lack of appropriate substrates (narrow substrate preferences), (H2) specific requirements for fruiting, (H3) lack of habitats/connectivity, and ( $\mathrm{H} 4)$ phylogeographical reasons (climate, dispersal history, biotic interactions, etc.). In this paper, we aim to estimate habitat continuity and connectivity, occupancy rate, substrate and habitat dynamics, as well as thoroughly delimit the substrate niche of Pleurotus calyptratus based on the 6-year monitoring of two local populations of this species in the Eastern Ukraine, using both fruit bodybased survey and environmental DNA detection approaches.

\section{Materials And Methods}

\section{Study area and design}

The study area is situated in Eastern Ukraine, within the Kharkiv administrative region. According to "A grid-based map for the Biogeographical Regions of Europe", the territory lies on the border between Continental and Steppic biogeographical regions (Cervellini et al. 2020). According to WorldClim 2.1 dataset, which provides aggregated climate data for 1970-2000 years, the annual mean temperature for that territory ranged from 6.7 to $7.5^{\circ} \mathrm{C}$, the average maximum temperature of warmest month was estimated at $23-24{ }^{\circ} \mathrm{C}$, the average minimum temperature of coldest month was estimated at $-11--12$ 
${ }^{\circ} \mathrm{C}$, and the annual precipitation constituted $530-590 \mathrm{~mm}$ (Fick \& Hijmans 2017). Most of the area is covered by arable land; deciduous and coniferous forests are distributed unevenly and cover approximately $12 \%$ of the region (Buchhorn et al. 2020). Most common tree species include pedunculate oak (Quercus robur L.), Scots pine (Pinus sy/vestris L.), maples (Acer platanoides L., A. campestre L., A. tataricum L. and introduced $A$. negundo L.), lime (Tilia cordata Mill.) and common ash (Fraxinus excelsior L.), followed by aspen and poplars (Populus tremula L., P. alba L.), birches (Betula pendula Roth and $B$. pubescens Ehrh.) and black alder (Alnus glutinosa (L.) Gaertn.) (Kuzemko et al. 2018).

For our research we have chosen two representative sites in Eastern Ukraine. Both of them are deciduous forests dominated by Quercus robur, Acer platanoides, Tilia cordata, and Fraxinus excelsior (Fig. 1). Within the sites, aspen and poplar (both Populus tremula and Populus alba, as well as their hybrids) were represented primarily by homogeneous stands from $12 \mathrm{~m}^{2}$ (single-tree stand) to 8.4 ha, separated from each other by oak-mapple-lime-dominated deciduous forest. Aspen and poplar stands occupied either natural forest gaps or formerly clearcut areas. Maximum age of the stands was inferred based on local forest survey documentation (Kostyashkin \& Hlushko 2009).

The first site is a ca. $6 \mathrm{~km}^{2}$ part of Homilsha Forest National Nature Park, which received its current protected status in 2005. The second site, Kharkiv Forest-Park, is a ca. $12 \mathrm{~km}^{2}$ protected forest located within the borders of the city of Kharkiv. During XVIII-XX centuries both areas were intensively managed so that large aspen stands occupied mostly post-clearcut sites, but for the last decade no clear-cuts have occurred there because of acquired protected status.

As an initial survey, within each site we mapped boundaries of all potential P. calyptratus habitats. By "habitat" we mean a homogeneous poplar stand or a standalone single tree, separated from other stands by more than $20 \mathrm{~m}$. Within the habitats we mapped all occurrences of $P$. calyptratus fruit bodies: in 2013 in Homilsha Forest, and in 2015 in Kharkiv Forest-Park. We treated every single aspen or poplar tree or log as a one "substrate unit" and we did not control for possible genetic differences among individual tree trunks. In total, we surveyed 397 substrate units. For each substrate unit we assessed tree position (standing or fallen), vitality (living, dying or dead), integrity (complete or broken, for dead trees), trunk cross-section area, fall type and contact with the ground (for fallen trees) and averaged trunk bark detachment (as proxy for decay stage). For the last measure we used 5-rank scale, where 1 corresponds to intact bark, 2 - less than $10 \%$ of trunk bark detached, $3-10-30 \%$ of bark detached, $4-$ near a half of total trunk bark detached, and 5 - more than a half of bark detached for the given trunk. We permanently marked each substrate unit with blaze marks attached to bark or, for the logs with detached bark, to wood. Since some substrate units within monitoring plots were re-described several times, we totally have a dataset of 484 descriptions, including 358 with the signs of $P$. calyptratus fruiting and 126 without it (repeated when fruit bodies were detected more than once on the same unit during monitoring surveys see below).

On the basis of the initial survey, we have chosen three plots in Homilsha Forest site for continuous detailed monitoring. All plots were 65-90 years old aspen stands formed after clear-cuttings, with areas 
between 3.5 and 8.4 ha. Each plot was surveyed 5 times in total, once per year in 2013-2018 (except 2015) in late April - May, during the peak of $P$. calyptratus fruiting season in the Eastern Ukraine, based on local observations. All the data were stored in SQLite database with the SpatiaLite extension and handled with the spatialite_gui software (Furieri 2014).

\section{Wood sampling and DNA detection in living trees}

To examine an ability of $P$. calyptratus to develop in living aspen and poplar trees, we extracted the total DNA from 9 of 10 collected kerns of living wood (1 kern was too firm to process it). Kerns from young trees (9-45 years old, calculated from year rings), were obtained using the increment borer sterilized by the fire of a petroleum gas burner and sawdust stored in separate zip-locks in frozen state at $-18^{\circ} \mathrm{C}$ for 1 year. Before taking the kern, a patch of the bark was removed with a sterilized knife from the tree to avoid sample contamination by the spores or mycelium from outside. Kerns were homogenized in a liquid nitrogen using a sterilized pestle and mortar. Total DNA was extracted with a DNAeasy Powersoil kit (Quiagen) following the protocol of the manufacturer with minor modifications $(+100 \mu$ l of PowerBead solution to get enough supernatant).

DNA of Pleurotus calyptratus in wood samples was detected using specific primers PCF CGGAACCTTGTCCTAAACGGACTT (forward) and PCR2 TGAACGAGGTTTTGTAGCTGTTTGGA (reverse), both written in 5'-3' direction, newly designed by the author OS. The primers cover the 5.8 RNA and a part of ITS2 region and produce an amplicon of ca $312 \mathrm{bp}$. Primer specificity was tested by the Primer-BLAST search against Genbank data, limited to Pleurotus genus, which showed them to be specific for $P$. calyptratus. Besides that, we performed an initial test for primers specificity against two alternative species of Pleurotus common in the studied area. We used these primers to run two PCR sets with DNA extractions from pure cultures of P.calyptratus (strain CWUPC2016, cultivated for 21 day before the extraction), P. pulmonarius (strain CWUPP2016, cultivated for 29 days) and $P$. ostreatus (strain CWUP02016, cultivated for 17 days). Cultures of all those species were isolated from fruiting bodies collected in one of the studied sites - Kharkiv Forest-Park. Cultures are stored in the collection of cultures of the Department of Mycology, CWU, Ukraine.

PCR for testing primers was conducted in $25 \mu$ volume with the following load: $12,5 \mu \mathrm{L}$ X PCR Master Mix (K1081, ThermoFisher Scientific), $1 \mu$ l forward primer PCF (10 pmol), $1 \mu \mathrm{l}$ reverse primer PCR2 (10 pmol), $5,5 \mu \mathrm{H} 2 \mathrm{O}, 5 \mu \mathrm{l}$ DNA sample. PCR conditions were: initial denaturation $10 \mathrm{~min}-95^{\circ} \mathrm{C} ; 40$ cycles $\left(95^{\circ} \mathrm{C}-30 \mathrm{~s}, 65^{\circ} \mathrm{C}-30 \mathrm{~s}, 72^{\circ} \mathrm{C}-30 \mathrm{~min}\right)$, final elongation $72^{\circ} \mathrm{C}-10 \mathrm{~min}$.

In both runs, primers successfully amplified the target fragment in $P$. calyptratus while producing no electrophoresis bands in 2 alternative species (Fig. 2).

PCR for samples of living wood was conducted in $25 \mu$ volume with the following load: $5 \mu$ l HOT FIREPol Blend Master Mix (Solis BioDyne), $0.5 \mu \mathrm{l}(10 \mathrm{pmol})$ forward primer PCF, $0.5 \mu \mathrm{l}(10 \mathrm{pmol})$ reverse primer PCR2, $6 \mu$ undiluted DNA, $13 \mu \mathrm{l} \mathrm{H2O}$. PCR conditions were: initial denaturation $15 \mathrm{~min}-95^{\circ} \mathrm{C} ; 38$ cycles $\left(95^{\circ} \mathrm{C}-30 \mathrm{~s}, 55^{\circ} \mathrm{C}-30 \mathrm{~s}, 72^{\circ} \mathrm{C}-1 \mathrm{~min}\right)$, final elongation $72^{\circ} \mathrm{C}-10 \mathrm{~min}$. 
Sequencing of samples that produced a clear band was conducted by Macrogen Europe with the same forward primer. The geographical variation of obatined sequences assessed using sequenses of $P$. calyptratus ITS fragments obtained from the UNITE database (Nilsson et al. 2019).

\section{Data analysis}

As previously reported, in Ukraine $P$. calyptratus forms easily detectable fruiting bodies during a short period of time, about several weeks in late April - early May, almost regardless of the weather conditions (Prylutskyi 2011). Considering this, we presumed that the probability of fruiting bodies detection while surveying the site in the appropriate time could reach maximum 1, according to MacKenzie approach (MacKenzie 2006; Halme 2010).

On the basis of this suggestion we calculated an overall site occupancy as a simple ratio between the number of poplar stands at which the species was detected, and the overall number of poplar stands (MacKenzie 2006). To examine a relationship between the area of poplar stand and the occupancy, we used binomial regression analysis implemented in the glm function of stats $\mathrm{R}$ package ( $\mathrm{R}$ Core Team 2020).

To analyze spatial patterns for aspen and poplar stands we used the nearest neighbour analysis, which assesses how far the current spatial events (potential habitats of $P$. calyptratus in our case) deviate from the stochastic pattern (Poisson's process) (Hammer 2009). Also this analysis provided a measure of expected mean distance between stands, which we treated as habitat connectivity measure (Calabrese \& Fagan 2004; Hammer 2020).

To reveal substrates' temporal turnover, we calculated Sørensen turnover (Baselga 2010) using betapart R-package (Baselga \& Orme 2012). This measure computes the dissimilarity for each locality between time 1 and time 2, considering the turnover and nestedness components of temporal change, and the sum of both values (overall change).

Occupancy and turnover were calculated in R 3.6.2 and RStudio software (R Core Team 2020, RStudio Team 2016). For the Nearest neighbour analysis, we used PAST 4.0 (Hammer et al. 2001). Maps were made in QGIS 3.10 (QGIS Development Team 2020).

\section{Results}

\section{Aspen and poplar stands distribution patterns}

Both sites showed similar patterns in aspen and poplar stand distribution. On both sites we observed large aspen and poplar stands (emerged mostly after clear-cuts) accompanied by plenty of small, fewtree-sized stands growing in natural forest gaps. The mapping of the stands and the Nearest neighbour analysis demonstrated that in Homilsha Forest they were on average of larger area and separated by lower distance than those in Kharkiv Forest-Park. Total inventory of $P$. calyptratus fruit bodies accordingly 
showed that the overall occupancy score was higher in Homilsha Forest (Table 1). Furthermore, the Nearest neighbour analysis showed significant clustering for both sites.

Table 1 Sites' properties.

\begin{tabular}{|lll|}
\hline Measure & $\begin{array}{l}\text { Site 1 (Homilsha } \\
\text { Forest) }\end{array}$ & $\begin{array}{l}\text { Site 2 (Kharkiv Forest- } \\
\text { Park) }\end{array}$ \\
$\begin{array}{l}\text { Centroid coordinates, dec. degrees (WGS84 } \\
\text { datum) }\end{array}$ & $\begin{array}{l}\text { E 36.32097, N } \\
49.60867\end{array}$ & E 36.24476, N 50.06223 \\
\hline Area, ha & 837.58 & 2343.42 \\
\hline Number of stands & 63 & 96 \\
\hline Area of the biggest stand, ha & 6.43 & 5.67 \\
\hline Mean stand's area, ha & 0.39 & 0.14 \\
\hline Overall occupancy & 0.38 & 0.29 \\
\hline $\begin{array}{l}\text { Observed mean distance between stands, } \\
\text { meters }\end{array}$ & 85.3 & 156.7 \\
\hline $\begin{array}{l}\text { Expected mean distance between stands, } \\
\text { meters }\end{array}$ & 124.9 & 210 \\
\hline Nearest neighbour index (R) & 0.68 & 0.74 \\
\hline Nearest neighbour Z-Score & -4.82 & -4.88 \\
\hline Nearest neighbour p-value & 1.4314 e-06 & 1.0434 e-06 \\
\hline
\end{tabular}

\section{Occupancy to area ratio for particular stand}

The probability of being occupied by $P$. calyptratus for a particular poplar stand significantly increases with the increase of the stand's area (Fig. 3). Full model outputs are given in Table 2.

Table 2. Estimated regression parameters, standard errors, z-values and P-values for the binomial regression analysis of relationship between occupancy rate and an area of poplar stands.

\begin{tabular}{|lllll|}
\hline & Estimate & Std. error & z value & P-value \\
\hline Intercept & -1.38713343 & 0.2464718818 & -5.627958 & $1.823553 \mathrm{e}-08$ \\
\hline Area, sq. $\mathrm{m}$ & 0.00145708 & 0.0003672663 & 3.967366 & $7.267147 \mathrm{e}-05$ \\
\hline Observations & 159 & & & \\
\hline R2 Tjur & 0.28 & & & \\
\hline
\end{tabular}


We tested 9 variables reflecting suitability of the substrate units (poplar standing trees or logs) for $P$. calyptratus (see Study area and design in Materials and Methods for more details). In the analysis, only one variable explicitly associated with the presence of $P$. calyptratus fruit bodies - the trunk bark integrity, i.e. a total percent of bark preserved during the decomposition process (starting from $100 \%$ for the healthy living trees). At the same time, dead trees on initial decay stages (over $90 \%$ bark coverage) made $58 \%$ of the total detected substrates (Fig. 4). Consequently, we may state that the most appropriate substrate for $P$. calyptratus fruiting is a dying or recently dead poplar tree with most of its bark intact.

\section{Substrate and habitat temporal turnover}

We detected a rapid substrate temporal turnover for $P$. calyptratus (Fig. 5), which means that each particular substrate unit was used by $P$. calyptratus for fruiting only for a short period of time, typically no more than 1 year. Therefore, the pool of appropriate substrates of $P$. calyptratus must be recovered on at least $60 \%$ annually to maintain currently observed abundancy of fruiting bodies in the long run.

To address the question how long the particular habitat (aspen or poplar stand) is suitable for $P$. calyptratus population, we repeatedly surveyed 3 aspen stands for 6 years, 2013-2018, data missed for 2015). Within each stand we outlined a different spatio-temporal pattern of $P$. calyptratus fruiting inside of a particular stand (Fig. 6).

\section{DNA detection in wood of living trees}

In this study we developed species-specific primers and successfully tested PCR-based methods for detection of $P$. calyptratus in living trees. Among nine tested kerns, two samples produced amplicons of expected length, pointing at the presence of the P. calyptratus DNA. Sequencing of these PCR products confirmed their assignment to $P$. calyptratus (NCBI IDs MT872344 and MT872345, obtained respectively from 17- and 38 years old aspen trees). One more sample produced a weak band and failed in sequencing.

The sequences obtained from the living wood were identical to each other, and differed in a single base pair from ITS of $P$. calyptratus fruit body collected in the same region (MT872346). The targeted fragment showed no geographical variation across all eleven sequences of $P$. calyptratus available in UNITE. MT872346 was identical to sequences from Austria, Estonia, Russia as well as South Korea and China. At the same time, all sequences were dissimilar from other species of the genus Pleurotus, with the closest Genbank BLAST match, $P$. djamor, at a level of about $97 \%$ identity.

Detection of $P$. calyptratus DNA in living, young trees with no signs of fungal colonization provisionally confirms that the mycelium of $P$. calyptratus inhabits the tree long before the fruitification occurs, although more data is required to determine when and how this event happens.

\section{Discussion}


$P$. calyptratus is not subjected to a lack of substrates within the study area, since almost any aspen or poplar tree might be suitable for fungus fruiting on the appropriate stage. The latter may be briefly described as dying or recently dead tree with predominantly undetached bark. Since this stage typically lasts for a short time (1, rarely 2-3 year), P. calyptratus demonstrates a high substrate temporal turnover $(0.6-1)$.

We suppose that intact bark prevents tree stem or log from the losses of moisture. The latter plays a significant role in the fruiting of $P$. calyptratus, whose fruiting season - late spring - is typically dry in the semi-arid climate of the Eastern Ukraine (Goncharenko et al. 2020). In addition we often visually observed a well-developed basidiomycete mycelia under the bark close to places where fruit bodies of $P$. calyptratus were detected. We presume that $P$. calyptratus mycelium develops in the nutrient-rich tree phloem, therefore it must be strongly dependent on the bark coverage, which protects phloem from desiccation and damage.

Detection of the DNA of $P$. calyptratus in the tissues of 17- and 38-years-old aspen trees with no visible signs of fungal colonization confirmed this hypothesis. We may suggest that the fungus colonizes trees many years earlier than the first fruit bodies appear.

Such a pattern is known in some wood-inhabiting fungi, e.g. Vuilleminia comedens (Nees) Maire, Peniophora spp., Colpoma quercinum (Pers.) Wallr. (Rayner \& Boddy 1988 , Boddy \& Heilmann-Clausen 2008), Fomes fomentarius (L.) Fr. (Baum et al. 2003), Daldinia spp. (Johannesson et al. 2001, Stadler et al. 2014), Heterobasidion annosum (Fr.) Bref. (Asiegbu et al. 2005), or Phellinus nigrolimitatus (Romell) Bourdot \& Galzin (Ovaskainen et al. 2013), but $P$. calyptratus, alongside with other wood-inhabiting agarics with fleshy fruit bodies, has not been reported before as a species capable of biotroph-necrotroph transition.

There are a few reports about molecular detection of Pleurotus spp. mycelia in living plant tissues, for instance from fox grape (Vitis labrusca - Pleurotus nebrodensis), and cacao (Theobroma cacao Pleurotus ostreatus) tree (Rubini et al. 2005, Brum et al. 2012, Rashmi et al. 2019). Also there was evidence of rapid colonization of barley (Hordeum vulgare) roots ex situ by Pleurotus djamor (LopezLlorca et al. 2006). Moreover, endophytic lifestyle is known for a wide range of fungi capable of nematophagy, which is also true for several Pleurotus species (Lopez-Llorca et al. 2006). We presume such biology to be widely distributed among other wood-inhabiting agarics, which requires further investigations, as well as reasons for $P$. calyptratus rarity in Northern and Western Europe.

Results of 6-years-long monitoring within three aspen stands support the assumption that mycelia of $P$. calyptratus are distributed much wider than substrate units appropriate to fungus fruiting.

The figure 6 shows that, even within the post-clearcut even-aged stands, trees perish not simultaneously, providing a sufficient amount of substrate units appropriate for fruiting of $P$. calyptratus over a period of time. The principal exceptions are old-growth stands (more than 80 years old for aspen), which dieback means a complete disappearance of appropriate substrates (Fig. 6, the northern part of the (b) stand). 
Apparently, young to middle-aged poplar stands (approximately under 50 years old) are not suitable for $P$. calyptratus fruiting as well due to lack of dying trees, but they can host a hidden, pre-fruiting populations.

If we presume that $P$. calyptratus follows this pattern, i.e. is widely distributed as latent mycelia and fruits only when the host tree is going to die, species' fruit bodies should eventually appear in almost any poplar stand. But that is not the case in Northern and Western Europe, which indicates the influence of other factors shaping the metapopulation biology of this species (Hanski 1998). We have detected a rather high habitat connectivity (nearest neighbour distance amounted to 124.9 and 210 meters for Homilsha Forest and Kharkiv Forest-Park respectively) and an occupancy rate (0.38 and 0.29 respectively) in both studied sites. Nearest neighbour analysis also revealed statistically significant clustering of poplar stands in both sites (Z-score -4.82 and -4.88 respectively), which suggest that the majority of observed small stands emerged after the decomposition of big ones. The level of habitat continuity and connectivity in the regions where $P$. calyptratus is considered to be rare needs further investigations.

Forest management practices might have a major impact on $P$. calyptratus distribution, since they are decisive for whether poplar forest will stand until its natural destruction or will be clear-cutted before. In the latter case habitat is destroyed before it becomes suitable for $P$. calyptratus fruiting. We cannot also exclude the influence of currently unknown biotic interactions with other poplar-dwelling species, such as animal spore vectors or fungal predecessors sharing the same woody substrate (Ottosson et al. 2014; Norros et al. 2015).

Consequently, the dynamic balance between colonization rate (spread of mycelia) and habitat quality and connectivity might play a crucial role in population dynamics of $P$. calyptratus and determine the species future in regions where it is considered to be rare.

\section{Conclusions}

Here we show that aspen- and poplar-dwelling fungus $P$. calyptratus demonstrates an ecological strategy which combines both strict substrate requirements and rapid substrate turnover, based on fruit body survey. At the same time, while $P$. calyptratus has strict requirements for fruiting, it colonizes aspen and poplar trees long before the latter become suitable for fungus fruiting and latently develops in tissues of a living plant, which was confirmed by detection of fungus DNA in a living plant tissues. Therefore, $P$. calyptratus exhibit a strategy, which has not been previously reported for agarics, but may be far more widely distributed than previously thought.

Mycelia of $P$. calyptratus are supposed to be widely distributed in aspen and poplar forest stands in Eastern Ukraine. While there are no evidence for considering $P$. calyptratus a threatened species in Eastern Ukraine, causes of its rarity in Northern and Western Europe need further investigations.

\section{Declarations}




\section{Ethics approval and consent to participate}

Not applicable.

\section{Consent for publication}

Not applicable.

\section{Competing interests}

The authors declare that they have no competing interests.

\section{Availability of data and materials}

The datasets used and analysed during the current study are available from the corresponding author on reasonable request.

\section{Funding}

The study was supported by the Rufford Small Grants Foundation (Project "Conservation of Rare Fungus Pleurotus calyptratus in Aspen Stands of Ukrainian Forest-Steppe" 2016-2017). Sequences were produced within Estonian Research Council project IUT20-30.

\section{Authors information}

\section{Affiliations}

Department of Mycology and Plant Resistance, V.N. Karazin Kharkiv National University, Kharkiv 61022, Ukraine

Oleh Prylutskyi

Institute of Ecology \& Earth Sciences, University of Tartu, Vanemuise 46, EE-51014 Tartu, Estonia Iryna Yatsiuk and Anton Savchenko

Laboratory of Molecular Diagnostic, National Scientific Center "Institute of Experimental and Clinical Veterinary Medicine", Kharkiv 61023, Ukraine

Maryna Kit and Oleksii Solodiankin

Faculty of Biological and Environmental Sciences, University of Helsinki, Helsinki 00014, Finland

Dmitry Schigel

\section{Contributions}


OP - conception, design of the work, data collection, statistical analysis, data interpretation, draft of the

work; IY - design of the work, data collection, data interpretation, significant revision; AS - design of the work, data collection, preparing a map of study area, significant revision; MK - data collection; OS design of the species-secific primer; DS - conception, review of the literature, significant revision. All authors read and approved the final manuscript.

\section{Corresponding author}

Correspondence to Oleh Prylutskyi (prylutskyi@karazin.ua)

\section{Acknowledgements}

We would like to thank the Rufford Small Grants Foundation, which supported the study. Also we are grateful to the Estonian Research Council, which gave us an opportunity to perform a part of molecular fungal detection work.

\section{References}

Andrew C, Heegaard E, Kirk PM, Bässler C, Heilmann-Clausen J, Krisai-Greilhuber I, Kuyper TW, Senn-Irlet B, Büntgen U, Diez J, Egli S, Gange AC, Halvorsen R, Høiland K, Nordén J, Rustøen F, Boddy L, Kauserud H (2017) Big data integration: Pan-European fungal species observations' assembly for addressing contemporary questions in ecology and global change biology. Fungal Biol Rev 31(2):88-98. doi:10.1016/j.fbr.2017.01.001

Asiegbu FO, Adomas A, Stenlid J (2005) Conifer root and butt rot caused by Heterobasidion annosum (Fr.) Bref. s.I. Mol Plant Pathol 6(4):395-409. doi:10.1111/j.1364-3703.2005.00295.x

Baselga A (2010) Partitioning the turnover and nestedness components of beta diversity: Partitioning beta diversity. Glob Ecol Biogeogr 19(1):134-143. doi:10.1111/j.1466-8238.2009.00490.x

Baselga A, Orme CDL (2012) betapart: an R package for the study of beta diversity. Methods Ecol Evol 3(5):808-812. doi:10.1111/j.2041-210X.2012.00224.x

Baum S, Sieber TN, Schwarze FW, Fink S (2003) Latent infections of Fomes fomentarius in the xylem of European beech (Fagus sy/vatica). Mycol Prog 2(2):141-148

Boddy L, Heilmann-Clausen J (2008) Chapter 12 Basidiomycete community development in temperate angiosperm wood. In: Boddy L, Frankland JC, van West P. (eds) Ecology of Saprotrophic Basidiomycetes, vol. 28. British Mycological Society Symposia Series. Elsevier, pp 211-237

Brum MCP, Araújo WL, Maki CS, Azevedo JL (2012) Endophytic fungi from Vitis labrusca L.('Niagara Rosada') and its potential for the biological control of Fusarium oxysporum. Genet Mol Res 11(4):41874197 
Brus DJ, Hengeveld GM, Walvoort DJJ, Goedhart PW, Heidema AH, Nabuurs GJ, Gunia K (2012)

Statistical mapping of tree species over Europe. Eur J For Res 131(1):145-157

Buchhorn M, Smets B, Bertels L, Roo BD, Lesiv M, Tsendbazar N-E, Herold M, Fritz S (2020) Copernicus Global Land Service: Land Cover 100m: collection 3: epoch 2019: Globe

Bundesamt für Naturschutz (2009) Rote Liste gefährdeter Tiere, Pflanzen und Pilze Deutschlands. BonnBad Godesberg. https://www.rote-liste-zentrum.de/ Accessed 23 Jul 2020

Calabrese JM, Fagan WF (2004) A comparison-shopper's guide to connectivity metrics. Front Ecol Environ 2(10):529-536. doi:10.1890/1540-9295(2004)002[0529:ACGTCM]2.0.C0;2

Caudullo G, de Rigo D (2016) Populus tremula in Europe: distribution, habitat, usage and threats. In: SanMiguel-Ayanz J, de Rigo D, Caudullo G, Houston Durrant T, Mauri A. (eds.), European Atlas of Forest Tree Species. Publ. Off. EU, Luxembourg, pp. e01f148+

Cervellini M, Zannini P, Musciano MD, Fattorini S, Jiménez-Alfaro B, Rocchini D, Field R, Vetaas OR, Irl SDH, Beierkuhnlein C, Hoffmann S, Fischer J-C, Casella L, Angelini P, Genovesi P, Nascimbene J, Chiarucci A (2020) A grid-based map for the Biogeographical Regions of Europe. Biodivers Data J 8:e53720. doi:10.3897/BDJ.8.e53720

Fick SE, Hijmans RJ (2017) WorldClim 2: new 1-km spatial resolution climate surfaces for global land areas. Int J Climatol 37(12):4302-4315. doi:10.1002/joc.5086

Finnish Environment Institute, Finnish Biodiversity Information Facility, IUCN (2019) The Web Service of the Red List of Finnish Species. https://punainenkirja.laji.fi/en. Accessed 25 Jul 2020

Furieri A (2014) spatialite_gui: a GUI-tool for SQLite / SpatiaLite. http://www.gaia-gis.it

GBIF.org (2020a) Pleurotus calyptratus. GBIF Occurrence Download doi:10.15468/dl.4gy3st

GBIF.org (2020b) Populus tremula. GBIF Occurrence Download doi:10.15468/dl.ufbkbt

Goncharenko I, Semenishchenkov Y, Tsakalos JL, Mucina L (2020) Thermophilous oak forests of the steppe and forest-steppe zones of Ukraine and Western Russia. Biologia (Bratisl). doi:10.2478/s11756019-00413-w

Halme P (2010) Developing tools for biodiversity surveys: studies with wood-inhabiting fungi. Dissertation, University of Jyväskylä.

Hammer $\varnothing$ (2009) New methods for the statistical analysis of point alignments. Comput Geosci 35:659666

Hammer $\varnothing$ (2020) PAST: PAleontological STatistics. Version 4.01. Reference manual 
Hammer O, Harper D, Ryan P (2001) PAST: Paleontological Statistics Software Package for Education and Data Analysis. Palaeontol Electron 4:1-9

Hanski I (1998) Metapopulation dynamics. Nature 396(6706):41-49

Holec J, Beran M (eds) (2006) Červený seznam hub (makromycetů) Českérepubliky [Red list of fungi (macromycetes) of the Czech Republic]. Príroda

Hyvärinen E, Juslén A, Kemppainen E, Uddström A, Liukko U-M (2019) Suomen lajien uhanalaisuus Punainen kirja 2019. Ympäristöministeriö \& Suomen ympäristökeskus, Helsinki

Johannesson H, Vasiliauskas R, Dahlberg A, Penttilä R, Stenlid J (2001) Genetic differentiation in Eurasian populations of the postfire ascomycete Daldinia loculata. Mol Ecol 10(7):1665-1677. doi:10.1046/j.1365-294X.2001.01317.x

Kålås JA, Viken Å, Henriksen S, Skjelseth S (eds) (2010) Norsk rødliste for arter 2010 / The 2010 Norwegian red list for species. Artsdatabanken, Trondheim

Knudsen H, Vesterholt J (2012) Funga nordica: agaricoid, boletoid, clavarioid, cyphelloid and gastroid genera. Nordsvamp, Copenhagen

Kostyashkin S, Hlushko H (2009) Local forest inventory as of 01/01/2009. Zmiiv Forestry Company

Kuzemko A, Didukh Y, Onyshchenko V, Sheffer Ya (eds) (2018) National habitat catalogue of Ukraine. FOP Klymenko Yu.Ya., Kyiv

Lopez-Llorca LV, Jansson H-B, Vicente JGM, Salinas J (2006) Nematophagous fungi as root endophytes. In: Microbial root endophytes. Springer, pp 191-206

MacKenzie DI (2006) Occupancy estimation and modeling: inferring patterns and dynamics of species occurrence. Academic Press

Mirek Z, Zarzycki K, Wojewoda W, Szeląg Z (eds) (2006) Red list of plants and fungi in Poland - Czerwona lista roślin i grzybów Polski. W. Szafer Institute of Botany, Kraków

Nilsson RH, Larsson K-H, Taylor AFS, Bengtsson-Palme J, Jeppesen TS, Schigel D, Kennedy P, Picard K, Glöckner FO, Tedersoo L, Saar I, Kõljalg U, Abarenkov K (2019) The UNITE database for molecular identification of fungi: handling dark taxa and parallel taxonomic classifications. Nucleic Acids Res 47(D1):D259-D264. doi:10.1093/nar/gky1022

Norros V, Karhu E, Nordén J, Vähätalo AV, Ovaskainen O (2015) Spore sensitivity to sunlight and freezing can restrict dispersal in wood-decay fungi. Ecol Evol 5(16):3312-3326. doi:10.1002/ece3.1589

Ottosson E, Nordén J, Dahlberg A, Edman M, Jönsson M, Larsson K-H, Olsson J, Penttilä R, Stenlid J, Ovaskainen $O$ (2014) Species associations during the succession of wood-inhabiting fungal 
Ovaskainen O, Schigel DS, Ali-Kovero H, Auvinen P, Paulin L, Nordén B, Nordén J (2013) Combining highthroughput sequencing with fruit body surveys reveals contrasting life-history strategies in fungi. ISME $\mathrm{J}$ $: 1-14$

Prylutskyi OV (2011) Distribution, ecological features and conservation of Pleurotus calyptratus (Lindblad) Sacc. (Agaricales) in Ukraine. Ukr Bot J 68(5):780-784

QGIS Development Team (2020) QGIS Geographic Information System. Open Source Geospatial Foundation Project. http://qgis.osgeo.org

R Core Team (2020) R: A language and environment for statistical computing. Foundation for Statistical Computing. Vienna, Austria. URL https://www.R-project.org/

Rayner ADM, Boddy L (1988) Fungal decomposition of wood. Its biology and ecology. Chicheste. John Wiley \& Sons Ltd.

Rogers PC, Pinno BD, Šebesta J, Albrectsen BR, Li G, Ivanova N, Kusbach A, Kuuluvainen T, Landhäusser SM, Liu H, Myking T, Pulkkinen P, Wen Z, Kulakowski D (2020) A global view of aspen: Conservation science for widespread keystone systems. Glob Ecol Conserv 21:e00828. doi:10.1016/j.gecco.2019.e00828

RStudio Team (2020) RStudio: Integrated Development for R. RStudio, PBC, Boston, MA URL http://www.rstudio.com/

Rubini MR, Silva-Ribeiro RT, Pomella AWV, Maki CS, Araújo WL, dos Santos DR, Azevedo JL (2005) Diversity of endophytic fungal community of cacao (Theobroma cacao L.) and biological control of Crinipellis perniciosa, causal agent of Witches' Broom Disease. Int J Biol Sci 1(1):24-33

Saar I, Oja J, Põldmaa K, Zettur I, Kõljalg U (2019) Red List of Estonian Fungi - 2019 update. Folia Cryptogam Est (56):117-126. doi:10.12697/fce.2019.56.12

SLU Artdatabanken (2020) Artfakta. In: Artfakta. https://artfakta.se/om. Accessed 25 Jul 2020

Soop K, Strid Å, Toresson HG (1995) Pleurotus calyptratus - slöjmusslingen - återfunnen i Sverige efter ett och ett halvt sekel. Jordstjärnan 16(3):55-61

Stadler M, Læssøe T, Fournier J, Decock C, Schmieschek B, Tichy H-V, Peršoh D (2014) A polyphasic taxonomy of Daldinia (Xylariaceae). Stud Mycol 77:1-143. doi:10.3114/sim0016

The Norwegian Biodiversity Information Centre (NBIC) (2019) Norwegian Red List 2015. Version 1.9. Checklist dataset. doi:10.15468/mx9gdc 
Větrovský T, Morais D, Kohout P, Lepinay C, Algora C, Awokunle Hollá S, Bahnmann BD, Bílohnědá K, Brabcová V, D’Alò F, Human ZR, Jomura M, Kolařík M, Kvasničková J, Lladó S, López-Mondéjar R, Martinović T, Mašínová T, Meszárošová L, Michalčíková L, Michalová T, Mundra S, Navrátilová $D$, Odriozola I, Piché-Choquette S, Štursová M, Švec K, Tláskal V, Urbanová M, VIk L, Voříšková J, Žifčáková L, Baldrian P (2020) GlobalFungi, a global database of fungal occurrences from high-throughputsequencing metabarcoding studies. Sci Data 7(1):228. doi:10.1038/s41597-020-0567-7

\section{Figures}

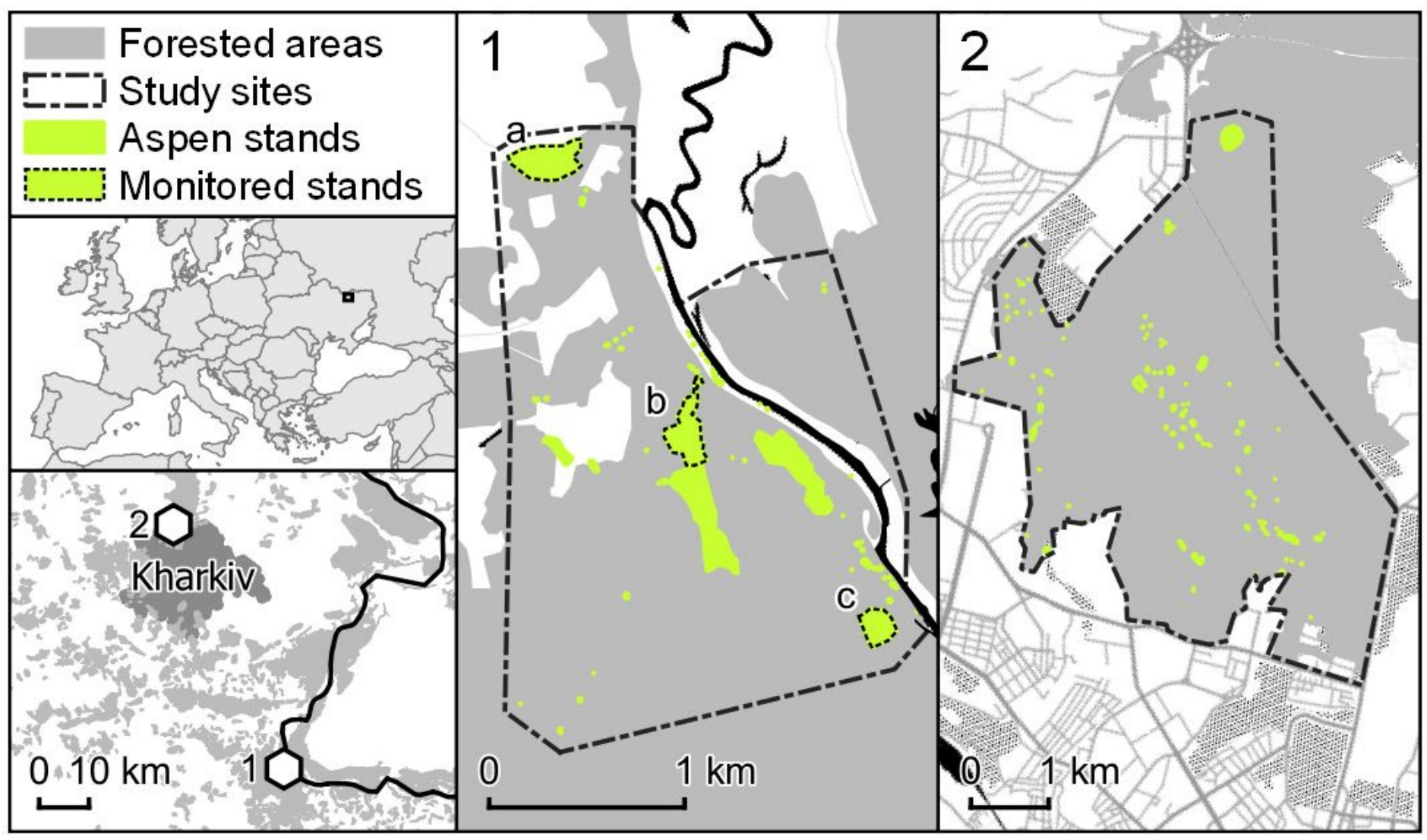

\section{Figure 1}

Study area. 1 - Homilsha Forest National Nature Park; 2 - Kharkiv Forest-Park. Insets: position in Europe and monitoring plots in Homilsha Forest. a, b, c - stands repeatedly surveyed in 2013-2018 years. Note: The designations employed and the presentation of the material on this map do not imply the expression of any opinion whatsoever on the part of Research Square concerning the legal status of any country, territory, city or area or of its authorities, or concerning the delimitation of its frontiers or boundaries. This map has been provided by the authors. 


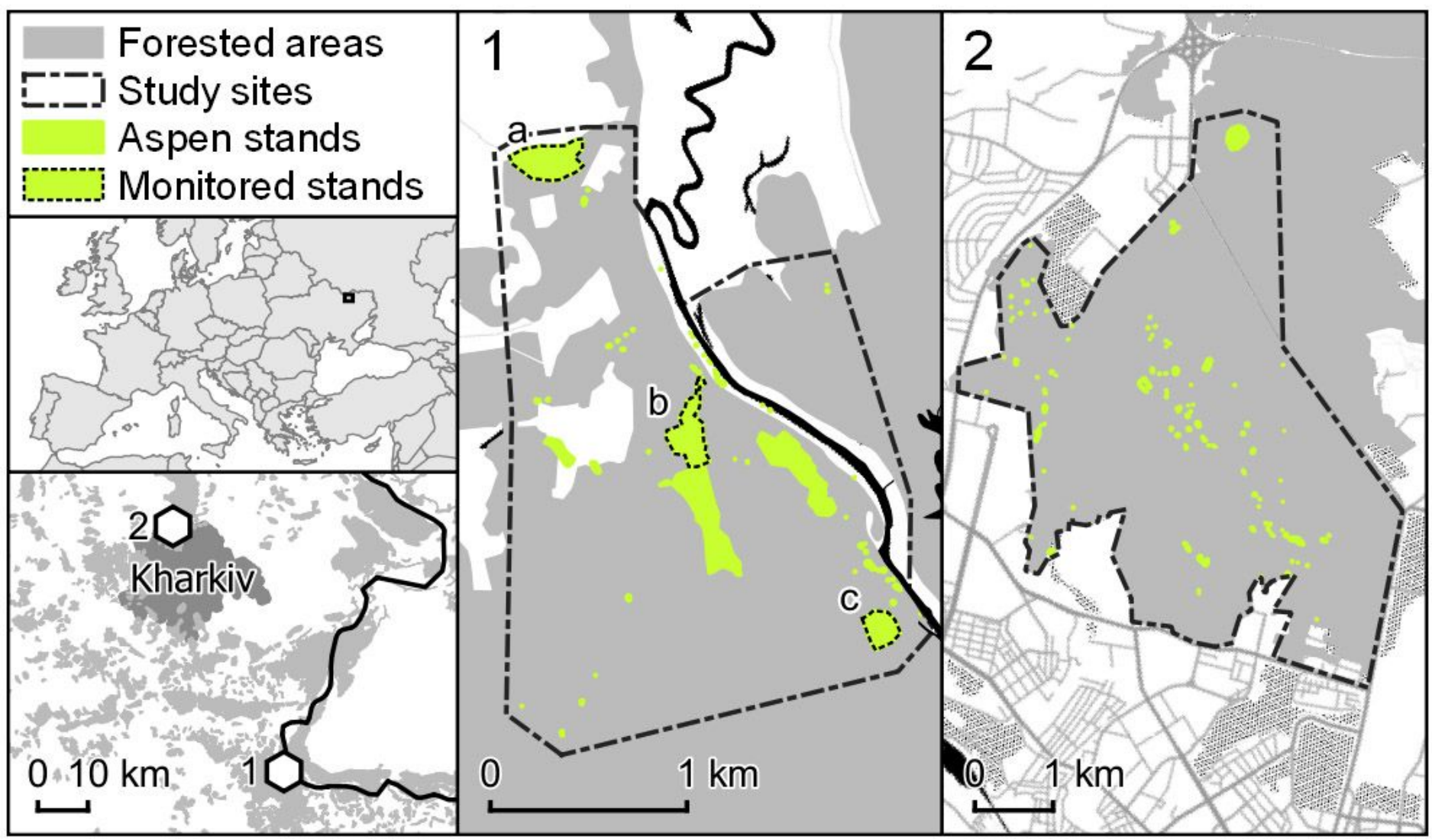

Figure 1

Study area. 1 - Homilsha Forest National Nature Park; 2 - Kharkiv Forest-Park. Insets: position in Europe and monitoring plots in Homilsha Forest. a, b, c - stands repeatedly surveyed in 2013-2018 years. Note: The designations employed and the presentation of the material on this map do not imply the expression of any opinion whatsoever on the part of Research Square concerning the legal status of any country, territory, city or area or of its authorities, or concerning the delimitation of its frontiers or boundaries. This map has been provided by the authors. 


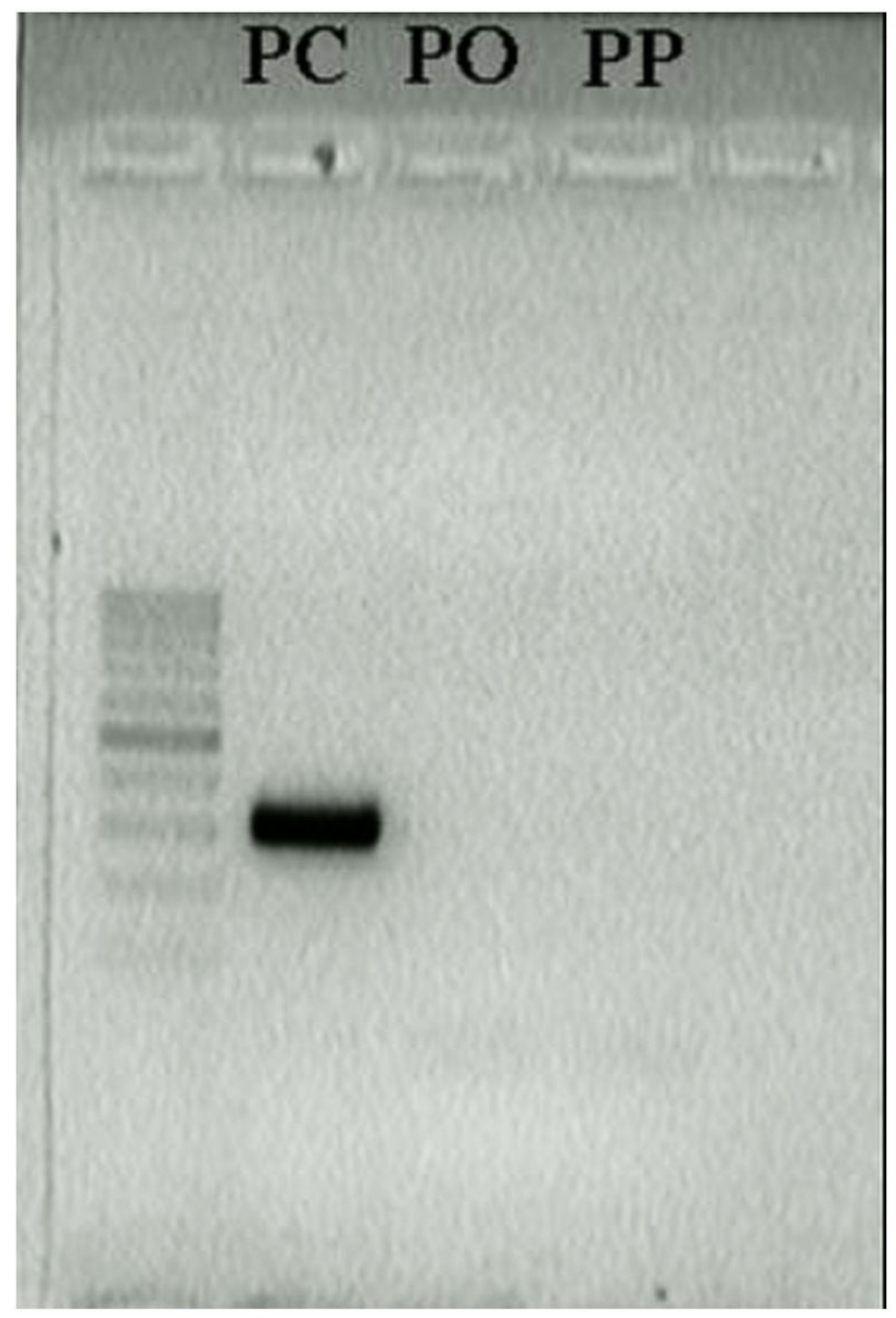

Figure 2

Tested primers PCF and PCR2 produced targeted amplicon near 312 bp in length in P. calyptratus (PC), while no bands in P. ostreatus (PO) and P. pulmonarius (PP). 


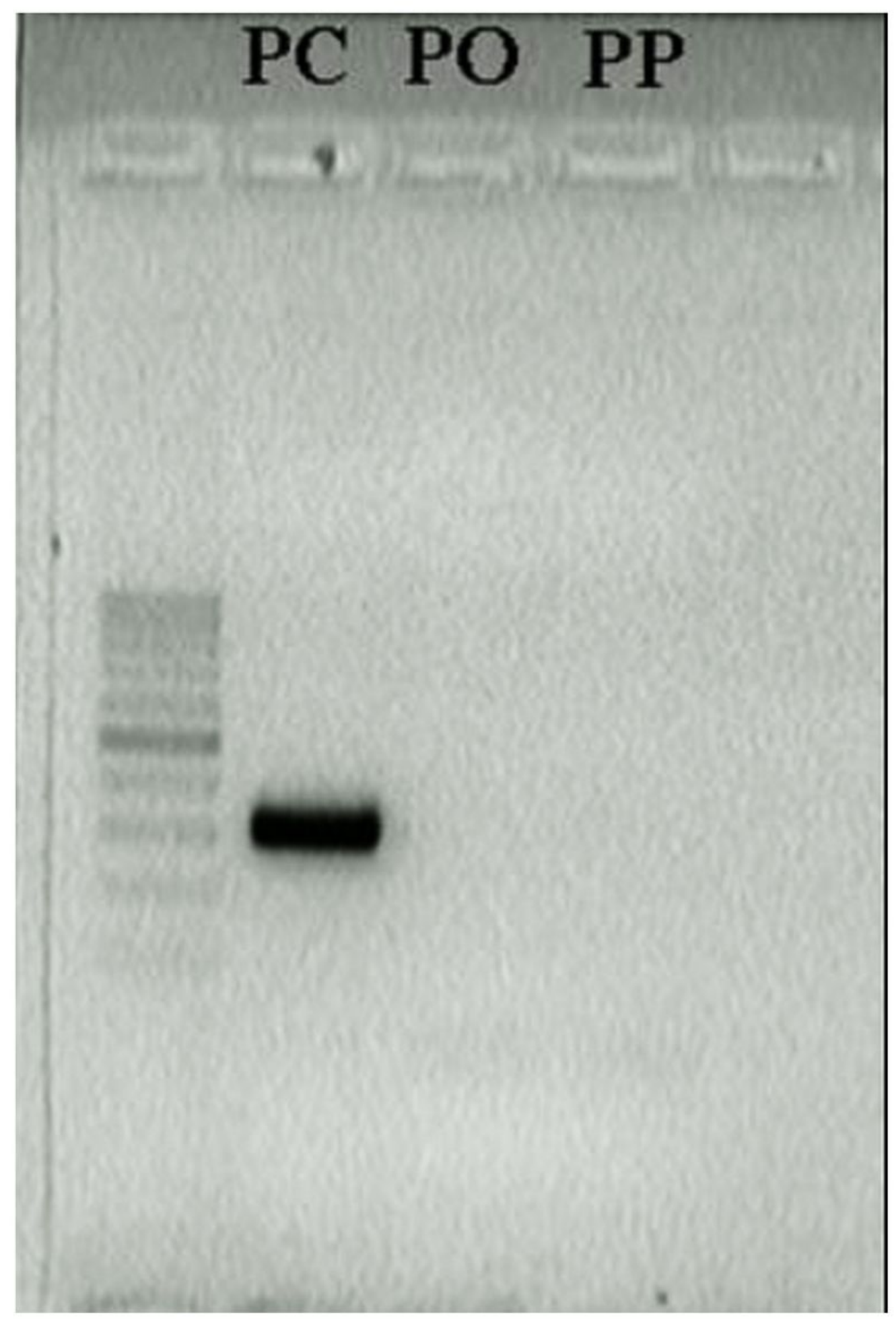

Figure 2

Tested primers PCF and PCR2 produced targeted amplicon near 312 bp in length in P. calyptratus (PC), while no bands in P. ostreatus (PO) and P. pulmonarius (PP). 


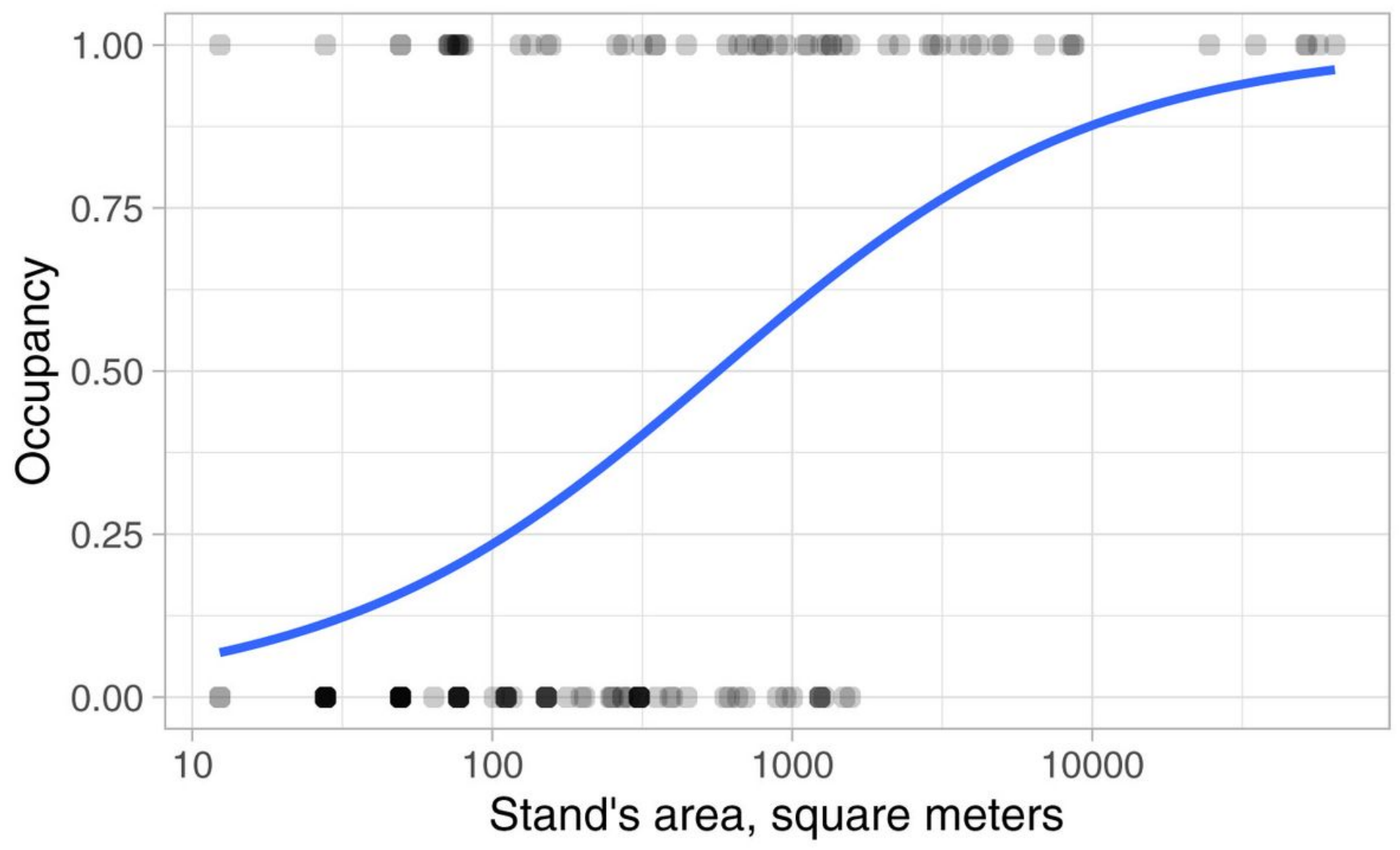

Figure 3

Relationship between occupancy rate and an area of poplar stands. 


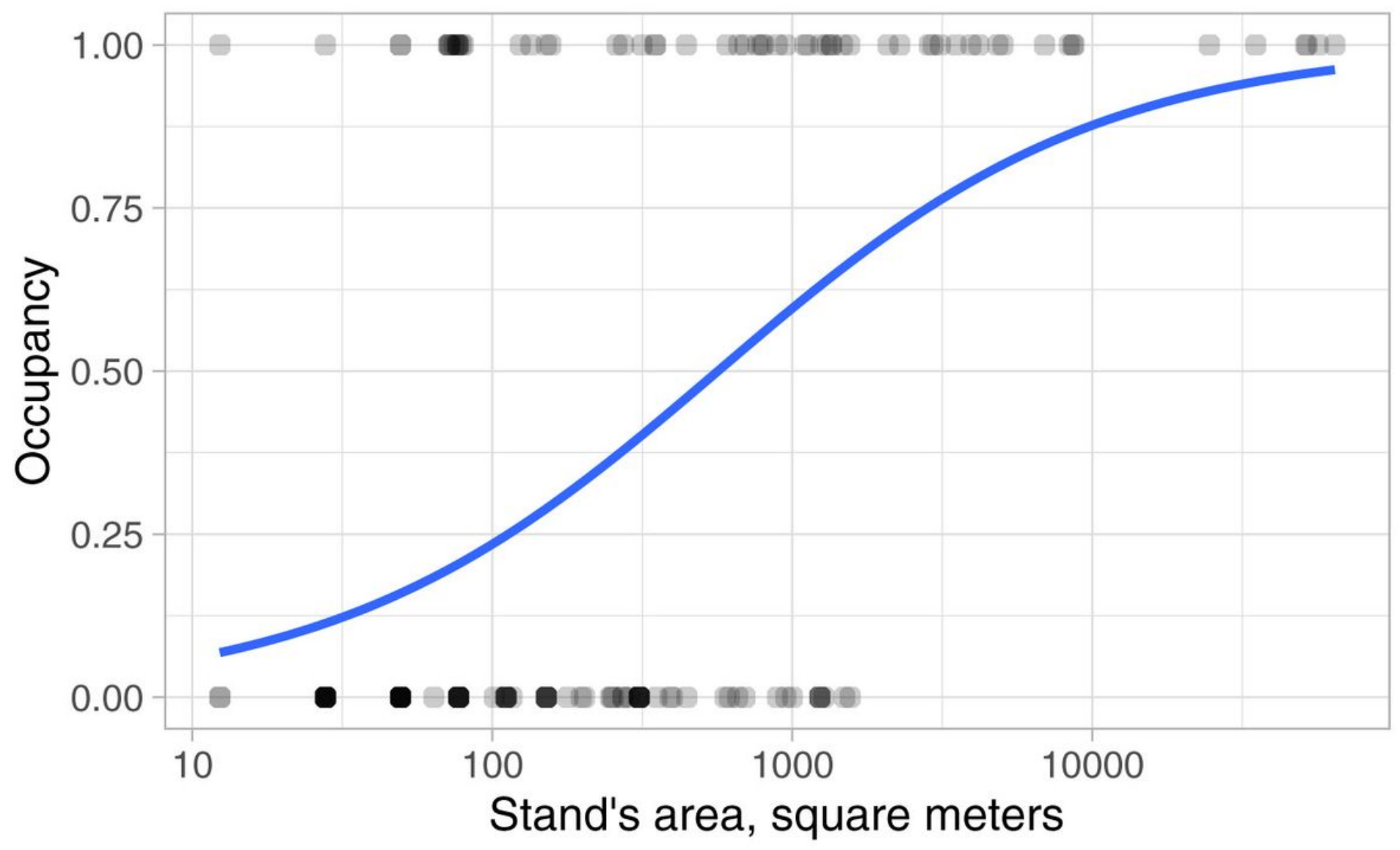

Figure 3

Relationship between occupancy rate and an area of poplar stands. 


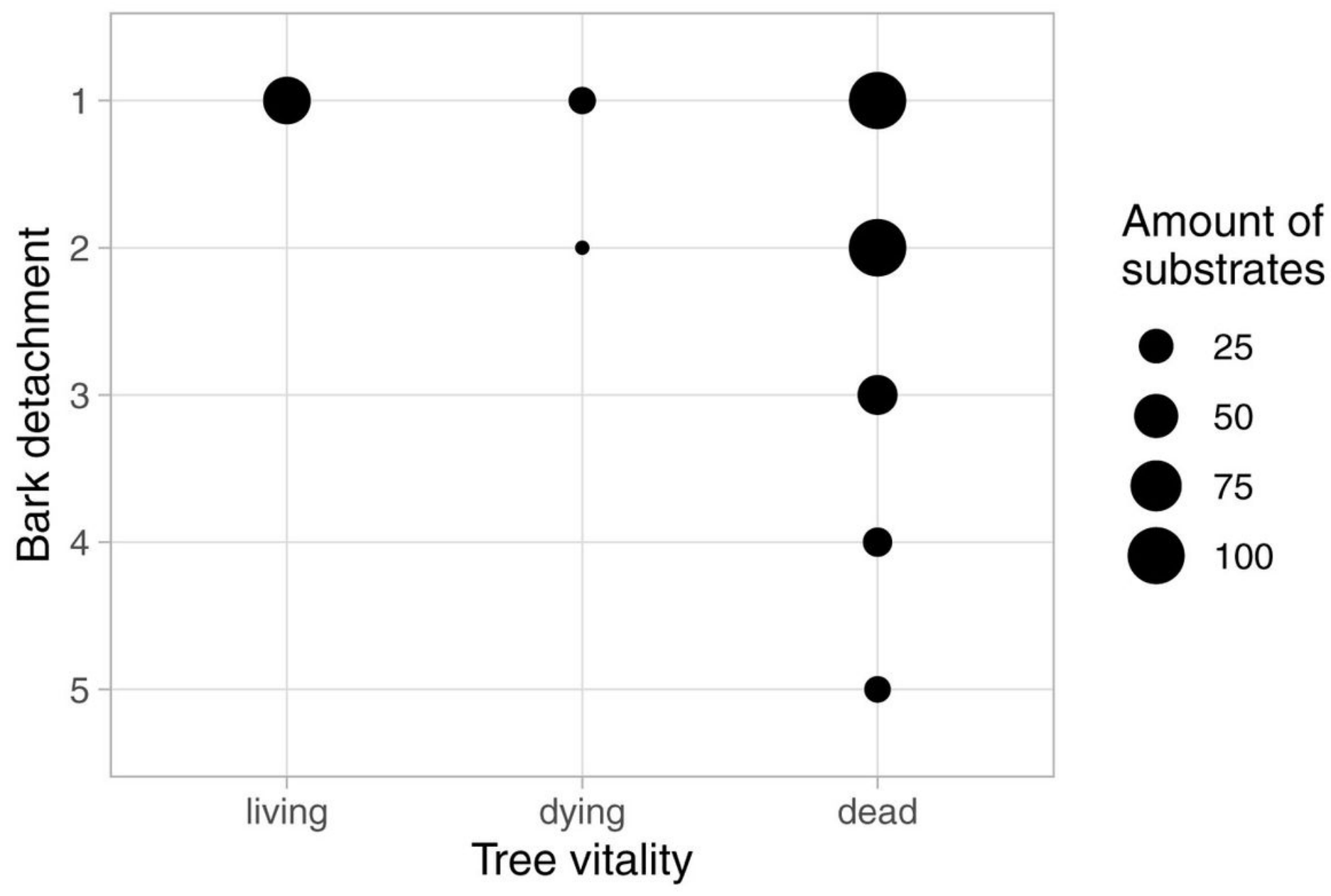

Figure 4

Distribution of detected substrates of P. calyptratus in two-factor grid (tree vitality vs. bark detachment rank, where 1 - intact bark, 5 - more than $50 \%$ of bark detached. See Materials and Methods for more details). 


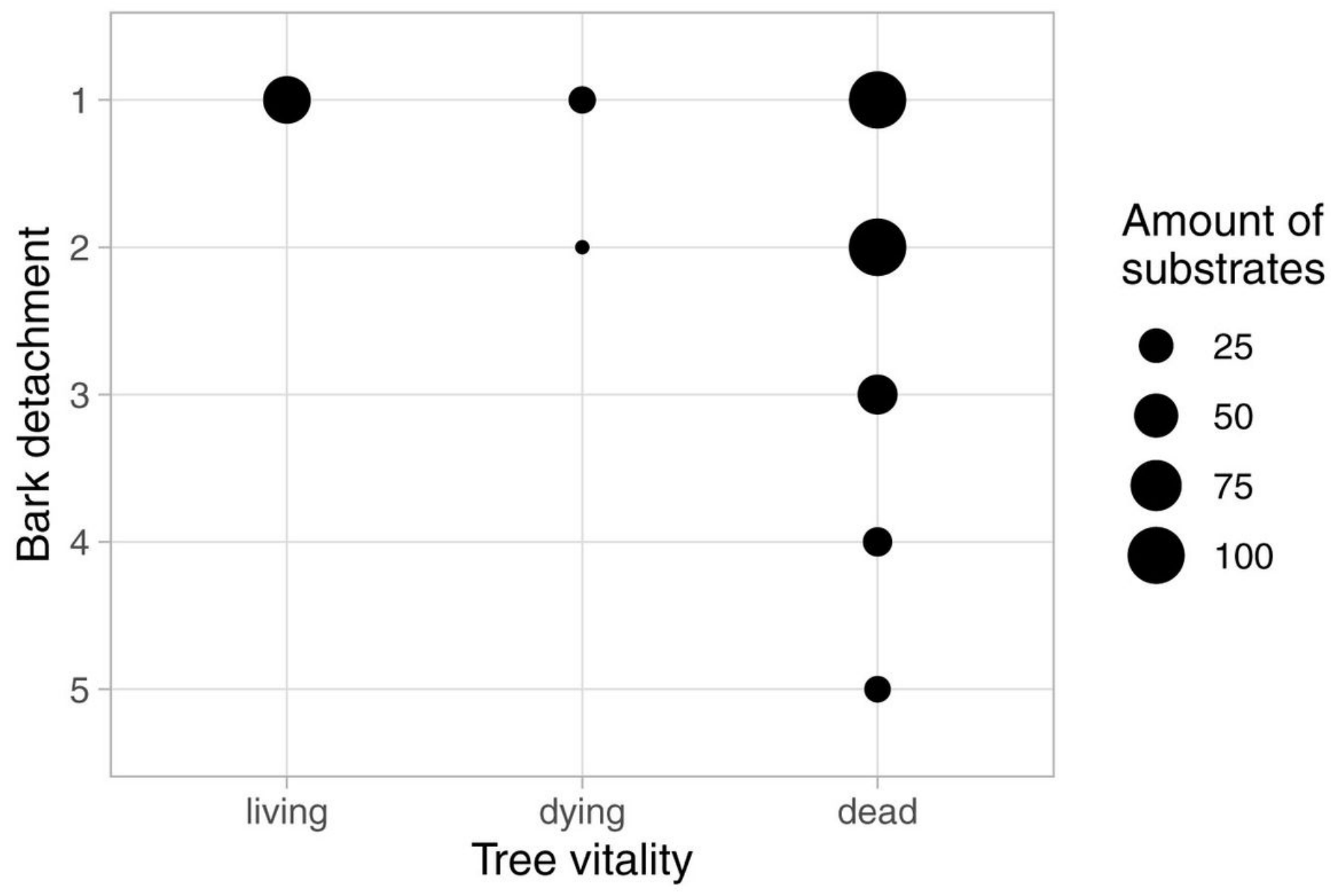

Figure 4

Distribution of detected substrates of P. calyptratus in two-factor grid (tree vitality vs. bark detachment rank, where 1 - intact bark, 5 - more than $50 \%$ of bark detached. See Materials and Methods for more details). 


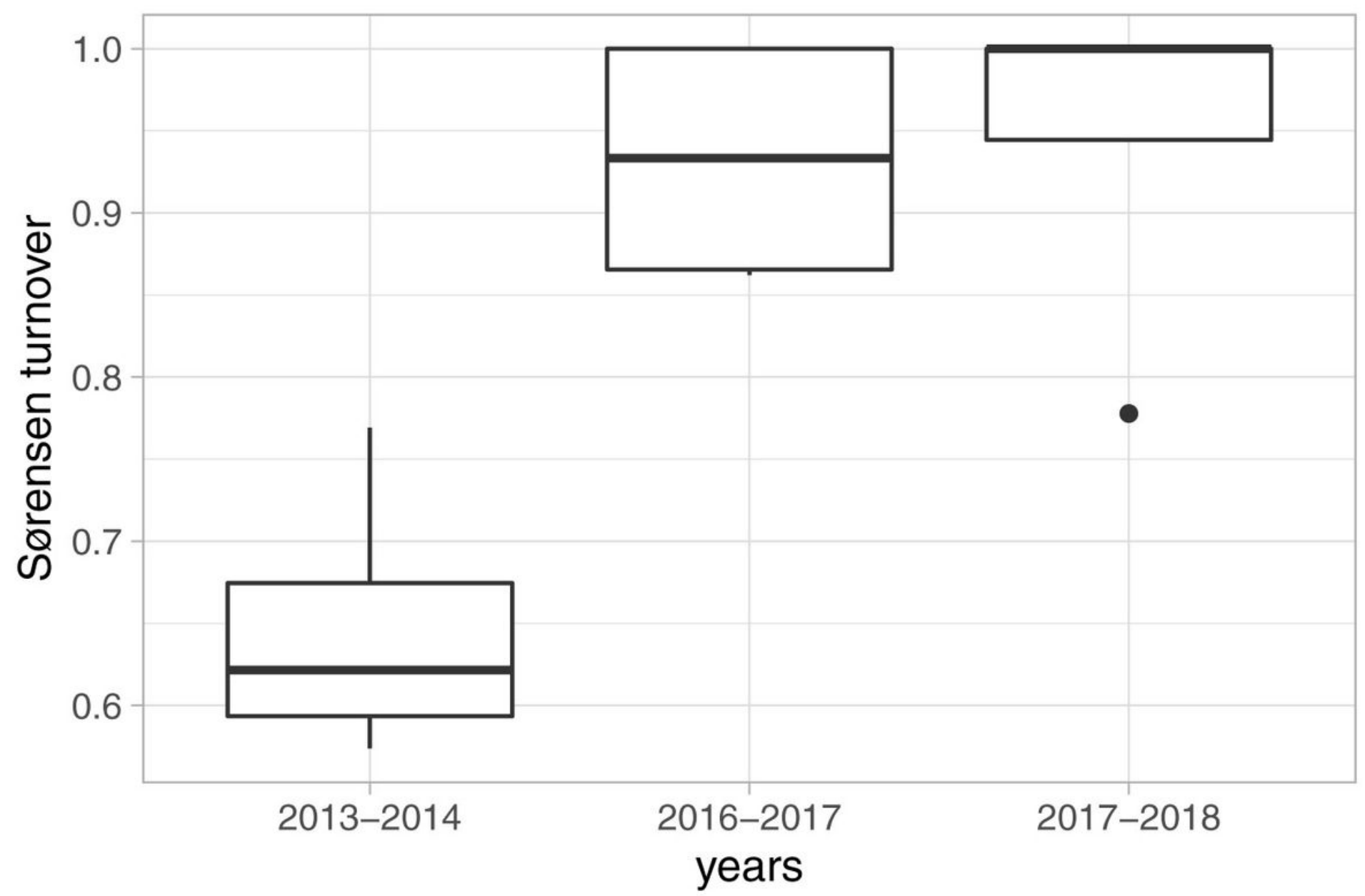

Figure 5

Substrate temporal turnover for P. calyptratus. Results of 6-year monitoring of 238 aspen trees/logs in Homilsha Forest National park, 2013-2018 (data gap for 2015). 


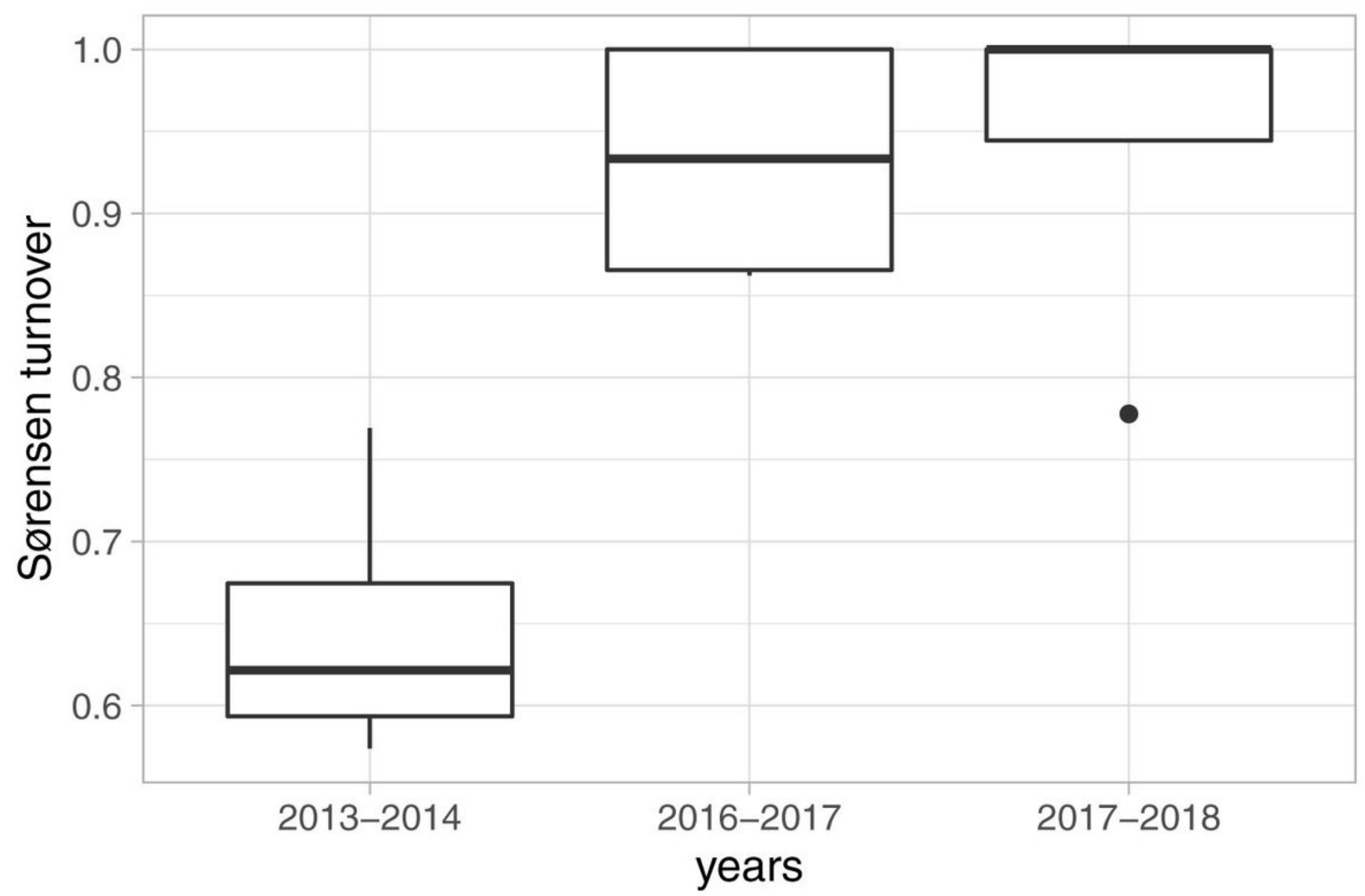

Figure 5

Substrate temporal turnover for P. calyptratus. Results of 6-year monitoring of 238 aspen trees/logs in Homilsha Forest National park, 2013-2018 (data gap for 2015). 
(a)

grid cell $50 \mathrm{~m}$
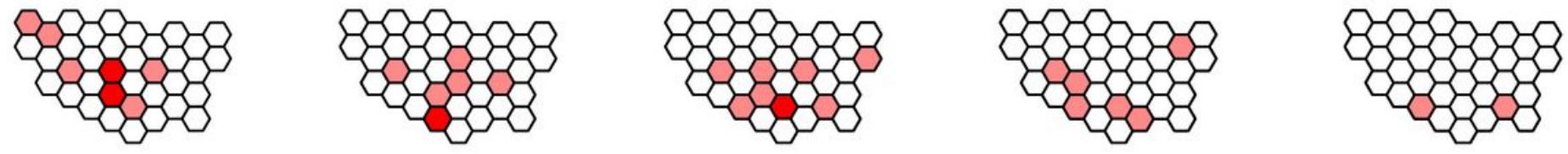

(b)
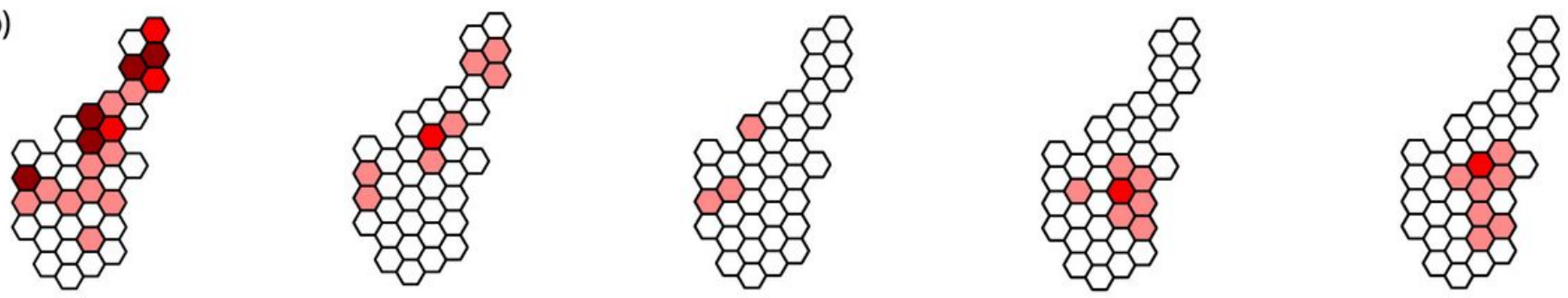

(c)
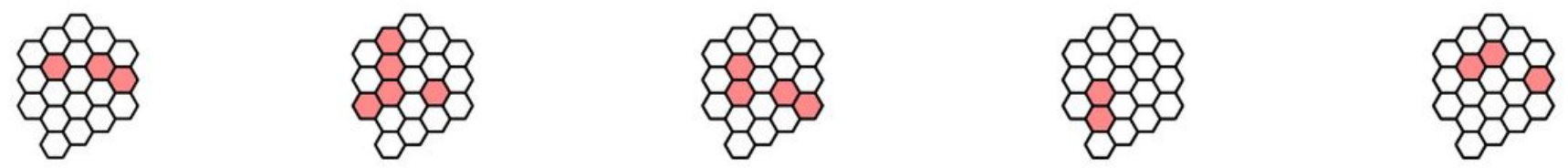

2013

2014

2016

2017

2018

$\square 0 \square 1-2 \square 3-5 \square 6$ - 20 substrates with fruit bodies of $P$. calyptratus

\section{Figure 6}

Fruiting of Pleurotus calyptratus for 5 years of observation. (a) mix of different deciduous trees with a major part of aspen, where last clear-cutting took place 100 years ago; (b) uneven-aged aspen stand (northern part 90 years since the last clear cut, southern part - 65 years); (c) even-aged aspen stand, last clear-cut 65 years ago. Note the stand b, where the fruiting of P. calyptratus gradually shifted from the north to the south due to the rapid substrate turnover, and the northern part has become totally overmature. 
(a)

grid cell $50 \mathrm{~m}$
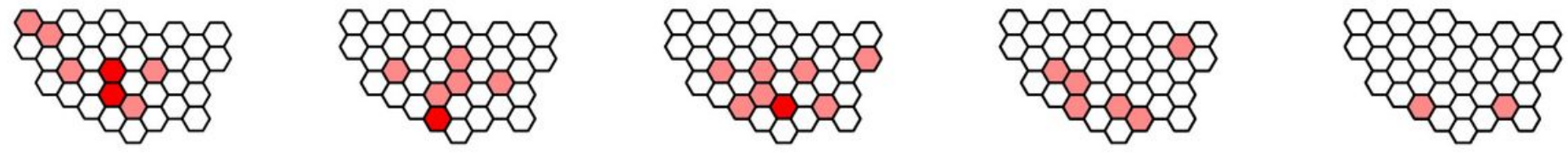

(b)
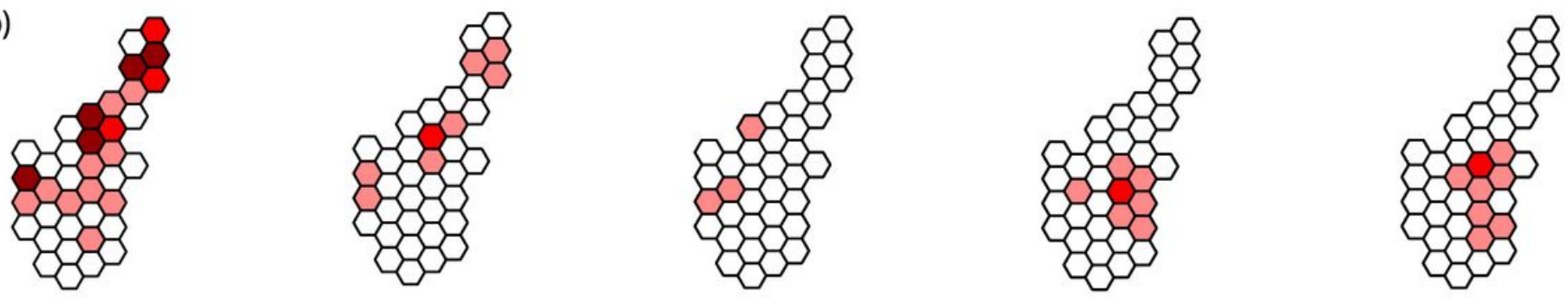

(c)
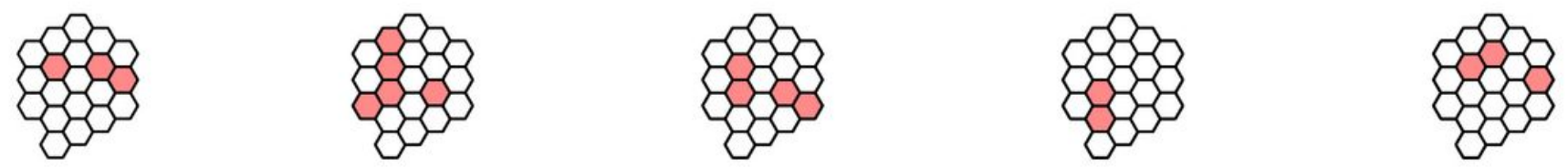

2013

2014

2016

2017

2018

$\square 0 \square 1-2 \square 3-5 \square 6$ - 20 substrates with fruit bodies of $P$. calyptratus

\section{Figure 6}

Fruiting of Pleurotus calyptratus for 5 years of observation. (a) mix of different deciduous trees with a major part of aspen, where last clear-cutting took place 100 years ago; (b) uneven-aged aspen stand (northern part 90 years since the last clear cut, southern part - 65 years); (c) even-aged aspen stand, last clear-cut 65 years ago. Note the stand b, where the fruiting of P. calyptratus gradually shifted from the north to the south due to the rapid substrate turnover, and the northern part has become totally overmature. 